e-ISSN; 2528-0325

ISSN; 2528-0317 | Vol. 2 No. 1 Juni 2017

Tasharruf: Journal

Economic

and

Business Of Islam

\title{
ANALISIS MODEL PEMBELAJARAN KEWIRAUSAHAAN BERBASIS MIND MAPPING Di SMK NEGERI 4 MAKASSAR
}

Oleh:

Agus Syam

agussyam76feunm@gmail.com

Dosen Program Studi Pendidikan Ekonomi Fakultas Ekonomi Universitas Negeri Makassar

\section{ABSTRAK}

This study was conducted to answer the problem "Is Entrepreneurship Learning Outcomes on Attitude and Behavior Basic Competence can Entrepreneurial Enhanced Through Cooperative Learning Mind Mapping". Thus, this research aims to improve learning outcomes in basic competency entrepreneurial attitude entrepreneur behavior after the application of the Mind Mapping. To that end, the results of this study would be useful: (1) theoretical, (a) for the academicleducational institutions, the subject of the information in the development of science, particularly in improving learning outcomes Entrepreneurship, (b) for researchers, as experience is extremely valuable in conduct scientific studies, and further research is as a comparison as well as reference materials for relevant research, (2) practical, (a) for the teacher, can assist teachers in improving student learning outcomes in the classroom through the implementation model of Mind Mapping, (b) for students, more motivated and interested in participating in the process of entrepreneurial learning in order to improve student learning outcomes in learning, and (c) for schools, provide information and input to the script on the use of models Cooperative learning activities.

Study is a classroom action research is descriptive, where the setting and subject of research conducted in 10 marketing class 3 which were 30 students at SMK Negeri 4 Makassar. This study conducted two cycles consisting of four activities: planning (planning), execution (action), observation (observation) and reflection. Data collection techniques used are observation, testing and documentation. With the increasing number of products to organize learning outcomes on average test scores 
e-ISSN; 2528-0325 ISSN; 2528-0317|| Vol. 2 No. 1 Juni 2017

Tasharruf: Journal Economic and Business

Of Islam

in the first cycle of the category of very less ie 51.42 percent increase to 88.57 percent which is well on the second cycle.

The results showed that the application of cooperative learning model to improve learning outcomes Script grade students of SMK Negeri 4 Makassar class 10 Marketing 3. As a follow-up suggested the need for the application of the developed models Mind Mapping learning as an alternative to increase motivation and learning outcomes in order to improve the quality of the learning process in schools, Cooperative learning Mind Mapping can be often applied not only on the competence of managing the product but other subjects as well, in case the student can focus more attention to learning when the learning process takes place, sought as early as possible to overcome the difficulties experienced, both by students and teachers in the learning process.

\section{Keywords: Mind Mapping Based Entrepreneurship Learning}

\section{PENDAHULUAN}

Pendidikan mempunyai peranan yang sangat penting dalam perkembangan hidup suatu bangsa. Dengan landasan pemikiran dan kesadaran tersebut pendidikan nasional sebagai usaha sadar untuk bangsa Indonesia mempertahankan kelangsungan hidupnya secara kontinu dan berkesinambungan perlu terus ditingkatkan dari generasi ke generasi. Pendidikan sebagai upaya manusia merupakan aspek dan hasil budaya terbaik yang mampu disediakan setiap generasi manusia untuk kepentingan generasi muda agar melanjutkan kehidupan dan cara hidup mereka dalam konteks sosio budaya. Oleh karena itulah, setiap masyarakat pluralistic di zaman modern senantiasa menyiapkan warganya yang terpilih sebagai pendidik bagi kepentingan kelanjutan (regenerasi) dari masing-masing masyarakat yang bersangkutan.

Pembelajaran yang terpusat pada guru sampai saat ini masih menemukan beberapa kelemahan. Kelemahan tersebut dapat dilihat pada saat berlangsungnya pembelajaran di kelas, interaksi aktif antar siswa dengan guru atau siswa dengan 
e-ISSN; 2528-0325 ISSN; 2528-0317|| Vol. 2 No. 1 Juni 2017

Tasharruf: Journal Economic and Business

Of Islam

siswa jarang terjadi. Siswa kurang terampil menjawab pertanyaan atau bertanya tentang konsep yang diajarkan, siswa kurang bisa bekerja dalam kelompok diskusi dan pemecahan masalah yang diberikan, mereka cenderung belajar sendiri-sendiri. Pengetahuan yang didapat bukan dibangun sendiri secara bertahap oleh siswa atas dasar pemahaman sendiri karena siswa jarang menemukan jawaban atas permasalahan atau konsep yang dipalajari. Kegiatan ini mengakibatkan siswa kurang ikut berpartisipasi dalam pembelajaran yang cenderung mengakibatkan mereka cepat bosan dan malas belajar. Melihat kondisi demikian, maka perlu adanya alternatif pembelajaran yang berorientasi pada bagaimana siswa belajar, menemukan sendiri informasi, menghubungkan topik yang sudah dipelajari dan yang akan dipelajari dalam kehidupan sehari-hari serta dapat berinteraksi multi arah baik bersama guru maupun selama siswa dalam suasana menyenangkan dan bersahabat. Salah satu alternatif yang dapat digunakan adalah pembelajaran mind mapping.

Metode pembelajaran mind mapping tentu saja bukan hal yang baru. Para guru sudah menggunakannya selama bertahun-tahun dalam bentuk kelompok laboratorium, kelompok tugas, kelompok diskusi, dan sebagainya. Namun penelitian terakhir di Amerika dan beberapa Negara lain telah menciptakan metode-metode pembelajaran mind mapping yang sistematik dan praktis yang ditujukan untuk digunakan sebagai elemen utama dalam pola pengaturan di kelas, pengaruh penerapan metode-metode ini juga telah didokumentasikan dan telah diaplikasikan pada kurikulum pengajaran yang lebih luas.

\section{METODE PENELITIAN}

\section{Pendekatan dan Jenis Penelitian}

Pendekatan yang digunakan dalam penelitian ini adalah pendekatan kualitatif deskiptif. Pendekatan kualitatif adalah pendekatan yang diperoleh dari siswa berupa data hasil observasi aktivitas, hasil wawancara serta kegiatan guru atau peneliti selama proses pembelajaran atau penelitian berlangsung. 
e-ISSN; 2528-0325 ISSN; 2528-0317|| Vol. 2 No. 1 Juni 2017

Tasharruf: Journal Economic and Business

Of Islam

Jenis penelitian ini menggunakan penelitian tindakan kelas (PTK). Penelitian dilaksanakan dalam 2 siklus. Tiap siklus terdiri dari 4 tahap yaitu : (1) perencanaan, (2) pelaksanaan, (3) Pengamatan atau observasi, dan (4) refleksi.

\section{Setting dan Subjek Penelitian}

Penelitian ini dilaksanakan di SMK Negeri 4 Makassar dengan mata pelajaran kewirausahaan pada kompetensi dasar sikap dan perilaku wirausaha. Subjek penelitian adalah seluruh siswa kelas 10 Pemasaran pada semester ganjil tahun pelajaran 2015/2016.

\section{Fokus Penelitian}

Untuk menjawab permasalahan yang telah disebutkan sebelumnya, ada beberapa faktor yang akan diselidiki. Faktor-faktor tersebut adalah sebagai berikut:

1. Faktor siswa, untuk melihat hasil belajar kewirausahaan dan sejauh mana siswa dapat menggunakan model pembelajaran kooperatif dalam menyelasaikan tugastugas/soal-soal kewirausahaan.

2. Faktor guru, yaitu bagaimana guru berfungsi sebagai pemimpin, fasilitator dan motivator dalam proses pembelajaran agar siswa lebih aktif dalam belajaranya.

3. Kegiatan belajar-mengajar, akan diselidiki apakah terjadi interaksi yang baik antara guru dengan siswa, siswa dengan siswa sehingga tercipta suasana dan lingkungan belajar-mengajar yang baik.

4. Faktor hasil yaitu dengan melihat hasil belajar siswa setelah pembelajaran.

\section{Prosedur Pelaksanaan Tindakan}

Penelitian ini berbentuk tindakan kelas yang dirancang dalam dua siklus. Pelaksanaan tindakan diawali dengan prapenelitian dan setiap siklus dilaksanakan sesuai dengan perubahan yang ingin dicapai, dapat dilihat gambar siklus di bawah ini.

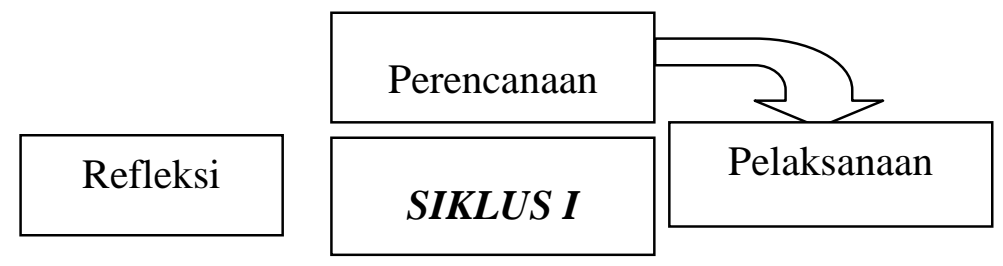


e-ISSN; 2528-0325 ISSN; 2528-0317||Vol. 2 No. 1 Juni 2017

Tasharruf: Journal Economic and Business

Of Islam

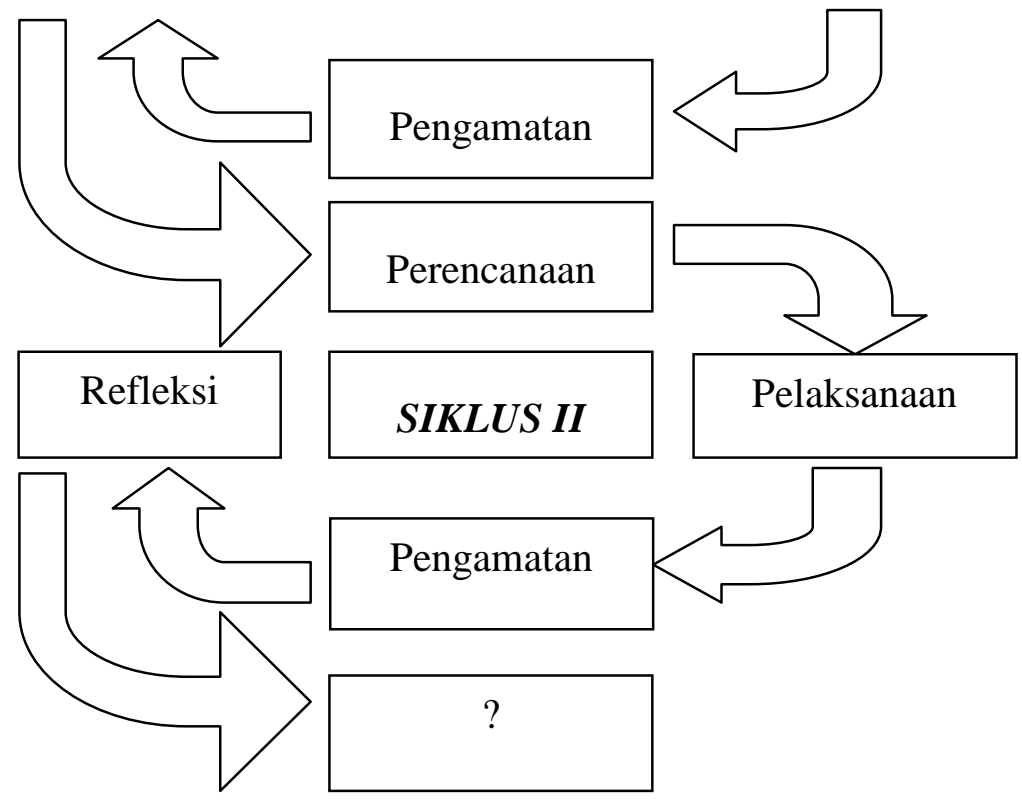

Gambar 1 .

Skema Penelitian Tindakan Kelas (Arikunto, 2010:16)

\section{Teknik Pengumpulan Data}

Teknik pengumpulan data yang digunakan dalam penilitian ini adalah:

1. Observasi, yaitu pengamatan dilakukan pada waktu tindakan sedang berlangsung.

Observasi dilakukan terhadap siswa dan guru dengan memperhatikan tingkahlakunya selama proses pembelajaran. Sehingga peneliti memperoleh gambaran suasana kelas dan peneliti dapat melihat secara langsung tingkah laku siswa, kerja sama dan komunikasi diantara siswa selama proses pembelajaran.

2. Dokumentasi, yaitu mengumpulkan data penelitian yang ada kaitannya dengan permasalahan dalam penelitian tindakan kelas. Metode dokumentasi ini peneliti gunakan untuk memperoleh data tentang siswa dan guru pada saat pembelajaran berlangsung.

3. Tes, peneliti akan menggunakan dua macam tes yaitu pre test dan post test. Pre test digunakan untuk mengukur seberapa jauh siswa telah memiliki kemampuan 
e-ISSN; 2528-0325 ISSN; 2528-0317|| Vol. 2 No. 1 Juni 2017

Tasharruf: Journal Economic and Business

Of Islam

mengenai hal-hal yang akan dipelajari dan tes ini dilaksanakan sebelum melaksanakan siklus I. Sedangkan Post test digunakan untuk mengukur apakah siswa telah menguasai kompetensi tertentu dan tes ini dilaksanakan pada akhir siklus.

\section{Analisis Data}

Analisis data dalam penelitian ini adalah dengan menggunakan analisis kualitatif dan kuantitatif. Data tentang hasil pengamatan dianalisis secara kualitatif sedangkan data tentang hasil belajar siswa dianalisis secara kuantitatif dengan menggunakan statistik deskriptif yaitu menghitung nilai rata-rata dan persentase hasil belajar.

Menurut Sudjiono (2006:43) mencari persentase (\%) nilai rata-rata adalah:

$\mathrm{P}=\frac{f}{\mathrm{n} r} \times 100 \%$

Dimana:

$\mathrm{P} \quad=$ Angka persentase

$f \quad=$ Frekuensi yang dicari persentasenya

$N \quad=$ Banyaknya sampel

Adapun untuk keperluan analisis data digunakan teknik kategori tingkat penguasaan materi. Pedoman yang digunakan untuk mengubah skor mentah yang diperoleh siswa menjadi skor standar (nilai). Tingkat penguasaan materi yang ditetapkan oleh Departemen Pendidikan dan Kebudayan dalam Wijayanti (2010:42) adalah sebagai berikut:

Tabel 1. Tingkat Penguasaan Materi

\begin{tabular}{ll}
\hline \multicolumn{1}{c}{ Nilai Hasil Belajar } & \multicolumn{1}{c}{ Kategori } \\
\hline $85-100$ & Sangat tinggi \\
$65-84$ & Tinggi \\
$55-60$ & Sedang \\
$35-54$ & Rendah \\
$0-34$ & Sangat rendah \\
\hline
\end{tabular}


e-ISSN; 2528-0325 ISSN; 2528-0317|| Vol. 2 No. 1 Juni 2017

Tasharruf: Journal Economic and Business

Of Islam

\section{Indikator Keberhasilan}

Indikator keberhasilan penelitian tindakan kelas ini adalah bila terjadi peningkatan skor rata-rata hasil belajar kewirausahaan dari siklus I ke siklus II dan apabila terjadi perubahan sikap dan minat siswa terhadap mata pelajaran kewirausahaan pada kelas 10 Pemasaran di SMK Negeri 4 Makassar setelah diberikan model pembelajaran mind mapping.

\section{HASIL PENELITIAN}

Hasil penelitian menunjukkan bahwa penerapan model pembelajaran mind mapping dapat meningkatkan hasil belajar siswa kelas 10 Pemasaran 3 SMK Negeri 4 Makassar. Sebagai tindak lanjut disarankan perlu adanya penerapan yang mengembangkan model pembelajaran Mind Mapping sebagai salah satu alternatif untuk meningkatkan motivasi dan hasil belajar sehingga dapat meningkatkan kualitas proses pembelajaran di sekolah, model pembelajaran Mind Mapping dapat lebih sering diterapkan bukan hanya pada kompetensi sikap dan perilaku wirausaha tetapi juga mata pelajaran lain, siswa sekiranya dapat lebih fokus memperhatikan pelajaran ketika proses belajar mengajar berlangsung, diupayakan sedini mungkin untuk mengatasi kesulitan-kesulitan yang dialami, baik oleh siswa maupun guru dalam proses pembelajaran.

\section{Pembahasan}

Pada analisis kualitatif diperoleh data dari pengamatan guru pada saat pembelajaran berlangsung dan tugas yang telah diberikan. Dalam hal ini yang menjadi fokus pengamatan adalah sikap, kesungguhan dan tanggapan-tanggapan siswa. Pada pertemuan awal siklus I, semangat dan keaktifan siswa mengikuti kegiatan belajar mengajar dan menyelesaikan tugas yang diberikan hampir tidak mengalami perubahan yang berarti dibandingkan dengan sebelum pelaksanaan penelitian ini. Tugas tentang Kewirausahaan yang diberikan pada pertemuan pertama, walaupun umumya siswa mengerjakan tugas tersebut dari pengamatan terhadap 
e-ISSN; 2528-0325 ISSN; 2528-0317|| Vol. 2 No. 1 Juni 2017

Tasharruf: Journal Economic and Business

Of Islam

jawaban yang diberikan dan penguasaan mereka terhadap jawaban itu menunjukkan bahwa mereka hanyalah mencontoh jawaban dari temannya yang dianggap mampu, tanpa mengetahui bagaimana penyelesaian yang sebenarnya dari tugas tersebut.

Selanjutnya, tugas yang diberikan kepada siswa umumnya masih sangat lemah mereka kuasai dalam konsep dasar yang seharusnya telah mereka kuasai. Utamanya dalam menyelesaikan soal, siswa yang demikian sangat kesulitan mengikuti materi yang diajarkan. Pada siklus ini motivasi siswa untuk memberikan jawaban yang benar pada setiap tugas yang diberikan masih sangat kurang. Dari segi sikap terhadap proses pembelajaran Kewirausahaan pada awal-awal pertemuan siklus I tidak jauh beda dengan proses pembelajaran sebelum penelitian dilakukan. Namun pada pertemuan-pertemuan berikutnya siswa sudah mulai tertarik. Ini terlihat dari berkurangnya siswa yang tidak hadir pada setiap belajar. Hal ini juga disebabkan karena contoh-contoh soal yang diberikan hampir seluruhnya berkaitan langsung dengan kegiatan sehari-hari siswa.

Pada awal penelitian berlangsung hingga berakhirnya siklus I tercatat sejumlah perubahan yang terjadi pada siswa yaitu:

a. Perhatian siswa terhadap proses pembelajaran makin baik. Dalam hal ini ditandai dengan siswa yang bertanya meningkat.

b. Keberanian siswa untuk menceritakan masalah di depan kelas. Hal ini ditandai dengan adanya beberapa siswa yang mengacungkan tangannya untuk naik ke depan kelas.

c. Jumlah siswa yang mengerjakan tugas mengalami peningkatan, sebaliknya siswa yang tidak mengumpulkan tugas yang diberikan mengalami penurunan jika dibandingkan dengan keadaan sebelum berlangsung penelitian ini.

Secara umum dapat dikatakan bahwa siklus ini siswa sudah mulai menampakkan sikap positif terhadap materi pelajaran. Hal ini diiringi dengan adanya beberapa siswa yang antusias menaggapi tugas-tugas yang di berikan walaupun yang banyak memberikan komentar maupun jawaban adalah berkisar pada siswa tertentu. 
e-ISSN; 2528-0325 ISSN; 2528-0317|| Vol. 2 No. 1 Juni 2017

Tasharruf: Journal Economic and Business

Of Islam

Proses pembelajaran pada siklus II ini tidak jauh berbeda dengan siklus sebelumnya saat berlangsungnnya proses pembelajaran. Siswa yang mengajukan pertanyaan hanya tertentu yakni siswa yang memperoleh nilai baik saja. Demikian halnya dengan jawaban dari pertanyaan balik guru, hampir tidak ada siswa yang menjawabnya. Dalam mengerjakan soal latihan yang diberikan umumnya siswa masih selalu memerlukan bimbingan dari guru. Walaupun demikian perhatian siswa terhadap pelajaran telah dianggap positif. Hal ini terlihat dari jawaban setiap siswa.

Pada akhir pertemuan siklus II terlihat kesungguhan siswa dalam mengikuti proses pembelajaran mengalami kemajuan. Hal tersebut terlihat oleh jawaban siswa menyelesaikan tugas-tugas dengan model tugas mandiri dan individual. Tugas ini di ramu sedemikian rupa sehingga siswa termotivasi untuk menyelesaikan tugas-tugas yang diberikan. Pada pelaksanaan siklus ini walaupun dari segi pemahaman materi hampir tidak ada perbedaan. Akan tetapi dari segi sikap siswa terhadap mata pelajaran, minat, berupa keinginan untuk mengetahui materi yang disajikan oleh guru ataupun kesungguhan siswa dalam proses pembelajaran mengalami kemajuan. Hal ini terlihat dari jumlah siswa yang hadir mengikuti pelajaran.

Pada siklus II, perubahan-perubahan dasar ditemukan pada siswa adalah sebagai berikut:

a. Perhatian siswa pada proses pembelajaran dibandingkan siklus sebelumnya semakin baik. Hal ini ditandai dengan semakin banyaknya jumlah siswa yang mengikuti proses pembelajaran pada mata pelajaran.

b. Kesungguhan siswa dalam mengerjakan tiap tugas yang diberikan juga mengalami peningkatan jika dibandingkan siklus I.

c. Kemampuan dan keberanian siswa untuk tampil di depan kelas meningkat. Hal ini ditandai dengan banyaknya siswa yang mengacungkan tangan untuk menceritakan masalah di depan kelas.

Pada awal siklus I umumnya siswa menganggap bahwa itu sesuatu yang tidak penting. Namun setelah berlangsungnya pelaksanaan siklus I hingga siklus II, dimana pada hampir semua contoh-contoh soal selalu dikaitkan dengan keadaan 
e-ISSN; 2528-0325 ISSN; 2528-0317 $\mid$ Vol. 2 No. 1 Juni 2017

Tasharruf: Journal Economic and Business

Of Islam

lingkungan sehingga pada akhirnya mereka mengerti tentang manfaat belajar penerapan pembelajaran model Mind Mapping dalam kehidupan.

Pada tahap selanjutnya, soal-soal latihan yang diberikan dan dikerjakan di kelas umumnya mereka masih sulit menjawab. Sebagian siswa biasanya mengerti penjelasan guru di kelas. Namun jika sudah belajar di rumah atau mengerjakan tugas, maka penjelasan guru sudah terlupa lagi. Apalagi kalau berselang beberapa hari setelah dijelaskan oleh guru. 
e-ISSN; 2528-0325 ISSN; 2528-0317 $\mid$ Vol. 2 No. 1 Juni 2017

Tasharruf: Journal Economic and Business

Of Islam

\section{KESIMPULAN}

Berdasarkan data hasil penelitian yang telah disajikan, maka dapat disimpulkan bahwa melalui penerapan model pembelajaran Mind Mapping di SMK Negeri 4 Makassar dapat meningkatkan hasil belajar siswa, yang ditandai dengan semakin meningkatnya hasil belajar siswa, tingkat keaktifan siswa, kualitas proses pembelajaran yang semakin meningkat, lebih fokus pula siswa terhadap materi yang disajikan oleh guru, konsentrasi siswa terhadap pelajaran semakin mengalami peningkatan dari siklus I ke siklus II.

\section{DAFTAR PUSTAKA}

Anonim, Undang-Undang No. 20 tahun 2003 Sistem Pendidikan Nasional.

Arikunto, Suharsimi. 2005. Penelitian Tindakan Kelas. Jakarta: PT. Bumi Aksara.

Dimyati dan Mudjiono. 2006. Belajar dan Pembelajaran. Jakarta: PT. Rineka Cipta.

Djamarah, Syaiful Bahri dan Aswan, Zain. 2006. Strategi Belajar Mengajar. Jakarta: PT. Rineka Cipta.

Dyah Ningrum (2011:62-63), Peningkatan Keaktifan Siswa Dalam pembelajaran Matematika Melalui Metode Mind Mapping Kelas 7 SMP Negeri 2 Karanganom. Skripsi: Fakultas Keguruan Jurusan Ilmu Pendidikan Matematika UM

Hamalik, Oemar. 2003. Proses Belajar Mengajar. Jakarta: PT. Bumi Aksara.

Holubec. 2003. Strategy For Teach Content And Thinking Skill. Alliya Bacon: Boston.

Ibrahim. 2001. Model Pembelajaran Kooperatif.Departemen Pendidikan Nasional UNRI. Pekanbaru

Isjoni. 2011. Pembelajaran KooperatiflMeningkatkan Kecerdasan Komunikasi Antar Peserta Didik. Yogyakarta: Pustaka Pelajar.

Laksana, Fajar. 2008. Manajemen Pemasaran/ Pendekatan Praktis. Yogyakarta: Graha Ilmu. 
e-ISSN; 2528-0325 ISSN; 2528-0317 $\mid$ Vol. 2 No. 1 Juni 2017

Tasharruf: Journal Economic and Business

Of Islam

Riyanto, H. Yatim. 2010. Paradigma Baru Pembelajaran. Jakarta: Kencana.

Slavin, Robert E. 2005. Cooperative Learning. Nusa media.

Slameto. 2010. Belajar dan Faktor-faktor yang Mempengaruhinya. Jakarta: Rineka Cipta.

Sudjiono, Anas. 2006. Pengantar Statistik Pendidikan. Jakarta: Rajawali Pers

Suhertian, Cristiana Demaja W. 2004. Pengaruh Penggunaan Bahan Ajar dan Gaya Belajar Terhadap hasil Belajar. Artikel Penelitian Dipublikasikan melalui www.edukasi.net. Diakses pada tanggal 16 Maret 2012.

Sutrisno. 2004. Sikap dan perilaku wirausaha/Bisnis dan Manajemen. Yudistira

Syah, Muhibbin. 2010. Psikologi Pendidikan/dengan Pendekatan Baru. Bandung: PT. Remaja Rosdakarya.

Wina, Sanjaya. 2007. Alat Peraga Komunikasi Pendidikan Untuk SPG. Jakarta. 